Article

\title{
Bioactive Potential of Extracts of Labrenzia aggregata Strain USBA 371, a Halophilic Bacterium Isolated from a Terrestrial Source
}

\author{
Carolina Díaz-Cárdenas ${ }^{1}$, Laura Yinneth Rojas ${ }^{2}$, Susana Fiorentino ${ }^{2}$, Monica P. Cala ${ }^{3} \mathbb{C}$, \\ Jorge I Díaz ${ }^{4}$, Freddy A. Ramos ${ }^{5}$, Jean Armengaud ${ }^{6}\left(\mathbb{D}\right.$, Silvia Restrepo ${ }^{7}$ and Sandra Baena ${ }^{1, *(\mathbb{D})}$ \\ 1 Unidad de Saneamiento y Biotecnología Ambiental, Departamento de Biología, \\ Pontificia Universidad Javeriana, P.O. Box 56710 Bogotá DC, Colombia; diazcardenascaro@gmail.com \\ 2 Grupo de Inmunobiología y Biología Celular, Pontificia Universidad Javeriana, \\ P.O. Box 56710 Bogotá DC, Colombia; rojasl.a@javeriana.edu.co (L.Y.R.); \\ susana.fiorentino@javeriana.edu.co (S.F.) \\ 3 Metabolomics Core Facility-MetCore, Vicepresidency for Research and Creation, Universidad de los Andes, \\ Cra 1 No. 18A-12, 111711 Bogotá DC, Colombia; mp.cala10@uniandes.edu.co \\ 4 Vicepresidency of Research and Creation, Universidad de los Andes, Cra 1 No. 18A-12, \\ 111711 Bogotá DC, Colombia; ji.diaz1@uniandes.edu.co \\ 5 Departamento de Química, Facultad de Ciencias, Universidad Nacional de Colombia-Sede Bogotá, \\ Carrera 30 \# 45-03, 110111 Bogotá DC, Colombia; faramosr@unal.edu.co \\ 6 Département Médicaments et Technologies pour la Santé (DMTS), CEA, INRAE, Université Paris Saclay, SPI, \\ 30200 Bagnols-sur-Cèze, France; jean.armengaud@cea.fr \\ 7 Chemical Engineering Department, Universidad de los Andes, Cra 1 No. 18A-12, \\ 111711 Bogotá DC, Colombia; srestrep@uniandes.edu.co \\ * Correspondence: baena@javeriana.edu.co
}

Academic Editor: Natalizia Miceli

Received: 27 March 2020; Accepted: 21 April 2020; Published: 29 May 2020

\begin{abstract}
Previous studies revealed the potential of Labrenzia aggregata USBA 371 to produce cytotoxic metabolites. This study explores its metabolic diversity and compounds involved in its cytotoxic activity. Extracts from the extracellular fraction of strain USBA 371 showed high levels of cytotoxic activity associated with the production of diketopiperazines (DKPs). We purified two compounds and a mixture of two other compounds from this fraction. Their structures were characterized by $1 \mathrm{D}$ and $2 \mathrm{D}$ nuclear magnetic resonance (NMR). The purified compounds were evaluated for additional cytotoxic activities. Compound $\mathbf{1}$ (cyclo (L-Pro-L-Tyr)) showed cytotoxicity to the following cancer cell lines: breast cancer 4T1 ( $\left.\mathrm{IC}_{50} 57.09 \pm 2.11 \mu \mathrm{M}\right)$, 4T1H17 $\left(\mathrm{IC}_{50} 40.38 \pm 1.94\right)$, MCF-7 $\left(\mathrm{IC}_{50} 87.74 \pm 2.32 \mu \mathrm{M}\right)$, murine melanoma B16 ( $\mathrm{IC}_{50} 80.87 \pm 3.67$ ), human uterus sarcoma MES-SA/Dx5 P-pg (-) (IC $50291.32 \pm 5.64)$ and MES-SA/Dx5 P-pg (+) ( IC $\left._{50} 225.28 \pm 1.23\right)$, and murine colon MCA 38 ( $\left.\mathrm{IC}_{50} 29.85 \pm 1.55\right)$. In order to elucidate the biosynthetic route of the production of DKPs and other secondary metabolites, we sequenced the genome of L. aggregata USBA 371. We found no evidence for biosynthetic pathways associated with cyclodipeptide synthases (CDPSs) or non-ribosomal peptides (NRPS), but based on proteogenomic analysis we suggest that they are produced by proteolytic enzymes. This is the first report in which the cytotoxic effect of cyclo (L-Pro-L-Tyr) produced by an organism of the genus Labrenzia has been evaluated against several cancer cell lines.
\end{abstract}

Keywords: Labrenzia aggregata USBA 371; cytotoxic activities; bioactive natural products; saline natural products; secondary metabolism; genome annotation; NMR characterization 


\section{Introduction}

More than one third of the approved drugs correspond to natural products or have been derived from compounds found in living organisms [1]. The discovery of new compounds from halophilic and halotolerant microorganisms has become increasingly important in natural products research [2-6] as these microorganisms represent reservoirs of novel bioactive metabolites with diverse groups of chemical structures [7]. Compounds isolated from deep-sea microorganisms could represent new anti-tumor drugs of interest [6], but organisms from similar environments such as saline ecosystems could also be considered as anti-tumor drug natural repositories, as shown in recent studies [2].

The Rhodobacteraceae family has been isolated mainly from marine habitats, in association with marine invertebrates such as corals, colonizing the surfaces of oysters and shells and in the rhizosphere of halophytes plants from coastal areas [8-10]. Labrenzia spp., a member of this family, possess biosynthetic genes for the production of non-ribosomal peptides (NRPS), polyketide synthases (PKS), bacteriocins and terpenoids [9,11], but few secondary metabolites have been isolated. To date, the described compounds are a polyketide pederin analogue, isolated from a free-living marine Labrenzia sp. PHM005, with cytotoxic activity against cancer cell lines A549 (ATCC CCL-185) (lung carcinoma, NSCLC); HT-29 (ATCC HTB-38) (colon adenocarcinoma); MDA-MB-231 (ATCC HTB-26) (breast adenocarcinoma) and PSN-1 (ATCC CRL-3211) (pancreas adenocarcinoma) [12], and a new catecholate-class siderophore designated Labrenzbactin with antimicrobial activity against Micrococcus luteus ATCC9341 and Ralstonia solanacearum SUPP1541 and cytotoxicity against P388 murine leukemia cells [13]. Cyclopropane fatty acids, derived from the primary metabolism of other marine Labrenzia spp., with activity against resistant multidrug pathogenic bacteria and fungi have been detected [14]. However, our knowledge on compounds produced by members of the genus Labrenzia is still limited, and there is a need to explore the metabolic potential of this halophilic genus as source of natural molecules with biological activity.

In a previous study [15], several cytotoxic compounds from more than 50 halophilic and halotolerant bacterial strains isolated from different Colombian saline environments were characterized. We described that Labrenzia aggregata USBA 371 cultured in saline tryptic soy broth (TSB) media supplemented with $3 \%(w / v) \mathrm{NaCl}$ produced a mixture of compounds, predominantly DKPs that were secreted to the extracellular medium and had cytotoxic activity. The cytotoxic effect of USBA 371 was related to the action of a diverse mixture of DKPs namely cyclo (Pro-Phe), cyclo (Leu-Phe), cyclo (Val-Phe), cyclo (Phe-Phe), cyclo (Pro-Leu), cyclo (His-Pro), cyclo (Pro-Val), cyclo (Pro-Ala) and cyclo (Pro-Tyr). The extract containing these DKPs presented a high cytotoxic effect against the adherent murine mammary cell carcinoma 4T1 and human mammary adenocarcinoma MCF-7 cell lines $\left(\mathrm{IC}_{50}<5.5 \mu \mathrm{g} / \mathrm{mL}\right)$ [15]. In addition to DKPs, this mix contained other compounds that did not match any of the databases used [15], indicating the need to further explore the metabolic diversity of the strain and the cytotoxic activity of these new compounds.

In the present study, we performed a metabolic profiling study of crude extracts from L. aggregata USBA 371 with high cytotoxic activity followed by the isolation and identification of the compounds responsible for the biological activity previously detected. To shed light on the metabolic potential of this strain, we sequenced and annotated its genome to identify its biosynthetic gene clusters. Using a proteogenomics approach, we detected the expression of proteins associated to enzyme complexes involved in the production of secondary metabolites. We show that L. aggregata USBA 371 is an important source of DKPs and characterize their cytotoxic activity, which had not been previously described in this halophilic genus.

\section{Results and Discussion}

\subsection{Metabolic Profiling of Crude Extracts from Chloroform Extractions}

As our earlier study [15] showed that a chloroform extract from the cell-free supernatants of L. aggregata USBA 371 culture was highly cytotoxic against 4 T1 and MCF7 cell lines, we decided to 
identify the principal metabolites of crude extracts obtained by sequential extraction with chloroform and ethyl acetate.

The LC/MS analysis of crude extracts obtained from chloroform extraction detected the presence of 29 putative compounds associated to peptides, alkaloids, fatty acids, glycerolipids and glycerophospholipids, as shown in Table 1.

The crude extract compounds were mainly the DKPs cyclo (L-Leu-L-Phe), cyclo (L-Leu-L-Leu), cyclo (L-Pro-L-Tyr) and cyclo (L-Ala-L-Pro). These are cyclic dipeptides produced as secondary metabolites by bacteria, fungi, plants and mammals $[16,17]$. Natural products containing DKP scaffolds are structurally diverse and resistant to proteolysis [18], and are known to have different functions. They are involved in quorum sensing [19] and have antifungal [20], antibacterial [20,21], anti-inflammatory [22] and cytotoxic activities [23,24], and are gaining great interest due to their bioactive potential [25]. This metabolic profiling confirms our previous results where we found high amounts of DKP in extracts from strain USBA 371 cultured in TSB 3\% (w/v) $\mathrm{NaCl}[15]$.

We isolated two DKPs and identified them as cyclo (L-Pro-L-Tyr) and cyclo (L-Tyr-L-Phe). They are hereafter referred to as compound 1 (Figures S1-S5) and compound 2 (Figures S6 and S7), respectively. We also isolated a fraction containing a mix of cyclo (L-Phe-L-Pro) (compound 3a) and cyclo (L-Ala-L-Pro) (compound 3b) (Figures S8 and S9). The compounds were identified by NMR spectroscopy, and their data were compared to published data [20,22,25-27]. Compound 1 corresponds to maculosin- 1 which has been reported as a secondary metabolite of bacteria and fungi $[20,28]$.

\subsection{Cytotoxic Activity Analysis of Major Compounds in Chloroform Extracts}

The cytotoxic activity of the crude extract, compounds $\mathbf{1}$ and $\mathbf{2}$, and the mix of compounds $\mathbf{3 a}$ and $\mathbf{3 b}$ was assessed against cell lines $4 \mathrm{~T} 1$ and MCF-7. The cytotoxic analysis showed activity in the $\mathbf{3 a}$ and $3 \mathbf{b}$ compound mix $\left(\mathrm{IC}_{50}<16.1 \pm 1.6 \mu \mathrm{g} / \mathrm{mL}\right.$ ) and in compound $\mathbf{1}\left(\mathrm{IC}_{50}<88 \mu \mathrm{M}\right)$, while compound $\mathbf{2}$ showed reduced cytotoxic activity $\left(\mathrm{IC}_{50}>250 \mu \mathrm{M}\right)$ (Table 2 and Figure S10A,B).

Our results show that the crude extract and a mixture of compounds $3 \mathbf{a}$ and $\mathbf{3 b}$ have greater cytotoxic effects than do the pure compounds. This could be due to the synergistic or additive activity which has been widely documented in plant extracts $[29,30]$. The search for compounds with antimalarial or antitumor activity has found that biological activity can be lost in extracts through processes to isolate active compounds. Consequently, promising extracts are ruled out because their activity disappears through fractionation [30].

The fact that these compounds show complete biological activity only when they interact in the crude extract [31,32] may be because that activity is conditioned not only on a clearly identified chemical structure, but also on a mixture of chemical structures that act together against a biological system such as a cell or an organism; in such a complex system of interactions, there very well may be multiple molecular targets [33]. These types of multiple interactions that explain why some extracts are more active than pure molecules are currently being studied through network pharmacology approximations [34,35]. This hypothesis suggests that although the biological activity of USBA 371 can be primarily attributed to DKPs, other compounds or chemical interactions are likely to contribute to its activity in the crude extract.

On the other hand, of the pure compounds we isolated, we were able to isolate a greater quantity of compound 1 than the others. Since compound $\mathbf{1}$ also demonstrated cytotoxic activity, we evaluated it against ten cell lines including murine and human tumor models and normal fibroblasts. Our results demonstrate the cytotoxic potential of compound $\mathbf{1}$ with high activity against the cell lines murine colon cancer MCA $38\left(\mathrm{IC}_{50}<40 \mu \mathrm{M}\right)$, breast cancer with high ALDH expression $4 \mathrm{~T} 1 \mathrm{H} 17\left(\mathrm{IC}_{50}<40 \mu \mathrm{M}\right)$ and lung cancer 3LL $\left(\mathrm{IC}_{50}<51.71 \mu \mathrm{M}\right)$ (Table 3). In contrast, no activity was detected against the myeloid acute leukemia K562 and U937 (Figure S11A-G) and we detected low activity, although not negligible, against the other cell lines analyzed (Table 3). 
Table 1. Metabolic profile of crude extract from strain USBA 371 by LC-MS analysis $(n=3)$.

\begin{tabular}{|c|c|c|c|c|c|}
\hline Compound & Molecular Formula & Molecular Weight (DB) g/mol & Mass Error (ppm) & Observed Ion & Description \\
\hline \multicolumn{6}{|c|}{ Peptides } \\
\hline Cyclo (L-leucyl-L-phenylalanyl) & $\mathrm{C}_{15} \mathrm{H}_{20} \mathrm{~N}_{2} \mathrm{O}_{2}$ & 260.1525 & 3 & $\mathrm{M}+\mathrm{H}$ & \multirow{10}{*}{$\begin{array}{l}\text { Cyclic dipeptides or diketopiperazines (DKPs) are a large class } \\
\text { of natural products with biological activities. } \\
\text { Dipeptide and tripeptides are incomplete breakdown product } \\
\text { of protein digestion or protein catabolism. }\end{array}$} \\
\hline Cyclo (L-leucyl-L-leucyl) & $\mathrm{C}_{12} \mathrm{H}_{22} \mathrm{~N}_{2} \mathrm{O}_{2}$ & 226.1681 & 4 & $\mathrm{M}+\mathrm{H}$ & \\
\hline Cyclo (L-Pro-L-Tyr) & $\mathrm{C}_{14} \mathrm{H}_{16} \mathrm{~N}_{2} \mathrm{O}_{3}$ & 260.151 & 1 & $\mathrm{M}+\mathrm{H}$ & \\
\hline Cyclo (L-Ala-L-Pro) & $\mathrm{C}_{8} \mathrm{H}_{12} \mathrm{~N}_{2} \mathrm{O}_{2}$ & 168.07 & 1 & $\mathrm{M}+\mathrm{H}$ & \\
\hline Aspartyl-Lysine//Gly Val Ser & $\mathrm{C}_{10} \mathrm{H}_{19} \mathrm{~N}_{3} \mathrm{O}_{5}$ & 261.1325 & 3 & $\mathrm{M}+\mathrm{Na}$ & \\
\hline Arg Gln Gln & $\mathrm{C}_{16} \mathrm{H}_{30} \mathrm{~N}_{8} \mathrm{O}_{6}$ & 430.2288 & 8 & $\mathrm{M}+\mathrm{Na}$ & \\
\hline Lysyl-Asparagine & $\mathrm{C}_{10} \mathrm{H}_{20} \mathrm{~N}_{4} \mathrm{O}_{4}$ & 260.1485 & 6 & $\mathrm{M}+\mathrm{H}$ & \\
\hline Tyr Trp Ile & $\mathrm{C}_{26} \mathrm{H}_{32} \mathrm{~N}_{4} \mathrm{O}_{5}$ & 480.2373 & 3 & $\mathrm{M}+\mathrm{H}$ & \\
\hline His Phe Trp & $\mathrm{C}_{26} \mathrm{H}_{28} \mathrm{~N}_{6} \mathrm{O}_{4}$ & 488.2172 & 4 & $\mathrm{M}+\mathrm{H}$ & \\
\hline Trp Tyr Phe & $\mathrm{C}_{29} \mathrm{H}_{30} \mathrm{~N}_{4} \mathrm{O}_{5}$ & 514.2216 & 4 & $\mathrm{M}+\mathrm{H}$ & \\
\hline \multicolumn{6}{|c|}{ Alkaloids } \\
\hline Anthcolorin G & $\mathrm{C}_{33} \mathrm{H}_{47} \mathrm{NO}_{4}$ & 521.7305 & 1 & $\mathrm{M}+\mathrm{H}$ & \\
\hline \multicolumn{6}{|c|}{ Fatty Acyls } \\
\hline Dodecanamide & $\mathrm{C}_{12} \mathrm{H}_{25} \mathrm{NO}$ & 199.1936 & 1 & $\mathrm{M}+\mathrm{H}$ & \multirow{9}{*}{$\begin{array}{l}\text { Fatty acids comprise components of the dual-membrane } \\
\text { envelope in bacteria. }\end{array}$} \\
\hline Linoleic acid & $\mathrm{C}_{18} \mathrm{H}_{32} \mathrm{O}_{2}$ & 280.2402 & 4 & $\mathrm{M}+\mathrm{H}$ & \\
\hline$\alpha$-Linolenic acid & $\mathrm{C}_{18} \mathrm{H}_{30} \mathrm{O}_{2}$ & 278.2246 & 4 & $\mathrm{M}+\mathrm{H}$ & \\
\hline $\mathrm{N}$-palmitoyl isoleucine//Arachidoyl glycine & $\mathrm{C}_{22} \mathrm{H}_{43} \mathrm{NO}_{3}$ & 369.3243 & 5 & $\mathrm{M}+\mathrm{H}$ & \\
\hline Oleamide & $\mathrm{C}_{18} \mathrm{H}_{35} \mathrm{~N}_{\mathrm{O}}$ & 281.2719 & 4 & $\mathrm{M}+\mathrm{H}$ & \\
\hline Palmitic acid & $\mathrm{C}_{16} \mathrm{H}_{32} \mathrm{O}_{2}$ & 256.2402 & 5 & $\mathrm{M}+\mathrm{H}$ & \\
\hline Oleic acid & $\mathrm{C}_{18} \mathrm{H}_{34} \mathrm{O}_{2}$ & 282.2559 & 3 & $\mathrm{M}+\mathrm{H}$ & \\
\hline $\mathrm{N}$-Butyl arachidonoyl amine & $\mathrm{C}_{24} \mathrm{H}_{41} \mathrm{NO}$ & 359.3188 & 4 & $\mathrm{M}+\mathrm{H}$ & \\
\hline Tetradecenoyl-CoA & $\mathrm{C}_{35} \mathrm{H}_{60} \mathrm{~N}_{7} \mathrm{O}_{17} \mathrm{P}_{3} \mathrm{~S}$ & 975.2979 & 2 & $\mathrm{M}+\mathrm{Na}$ & \\
\hline \multicolumn{6}{|c|}{ Glycerolipids } \\
\hline Monoacylglyceride (16:0) & $\mathrm{C}_{19} \mathrm{H}_{38} \mathrm{O}_{4}$ & 330.277 & 5 & $\mathrm{M}+\mathrm{H}$ & \multirow{2}{*}{$\begin{array}{l}\text { Glycerolipids are complex lipids formed by the condensation o } \\
\text { one, two, or three fatty acid molecules on glycerol. }\end{array}$} \\
\hline Diglyceride (44:6) & $\mathrm{C}_{47} \mathrm{H}_{80} \mathrm{O}_{5}$ & 724.6006 & 6 & $\mathrm{M}+\mathrm{Na}$ & \\
\hline \multicolumn{6}{|c|}{ Glycerophospholipids } \\
\hline $\begin{array}{c}\text { Lysophosphatidylcholine (LPC) } \\
\text { (16:1)//Phosphatidylethanolamine (PE) (19:1) }\end{array}$ & $\mathrm{C}_{24} \mathrm{H}_{48} \mathrm{NO}_{7} \mathrm{P}$ & 493.3168 & 4 & $\mathrm{M}+\mathrm{H}$ & \multirow{7}{*}{$\begin{array}{l}\text { Glycerophospholipids comprise components of the } \\
\text { dual-membrane envelope of Gram-negative bacteria with } \\
\text { biological functions in protein binding, transport of proteins } \\
\text { across inner membranes. }\end{array}$} \\
\hline Lysophosphatidylcholine (O-18:0) & $\mathrm{C}_{26} \mathrm{H}_{52} \mathrm{NO}_{7} \mathrm{P}$ & 521.3481 & 4 & $\mathrm{M}+\mathrm{H}$ & \\
\hline Phosphatidylethanolamine (39:5) & $\mathrm{C}_{44} \mathrm{H}_{78} \mathrm{NO}_{8} \mathrm{P}$ & 779.5465 & 2 & $\mathrm{M}+\mathrm{H}$ & \\
\hline Phosphatidylethanolamine (41:6) & $\mathrm{C}_{46} \mathrm{H}_{80} \mathrm{NO}_{8} \mathrm{P}$ & 805.5622 & 2 & $\mathrm{M}+\mathrm{H}$ & \\
\hline Phosphatidylethanolamine (39:4) & $\mathrm{C}_{44} \mathrm{H}_{80} \mathrm{NO}_{8} \mathrm{P}$ & 781.5622 & 6 & $\mathrm{M}+\mathrm{H}$ & \\
\hline Phosphatidylethanolamine (41:5) & $\mathrm{C}_{46} \mathrm{H}_{82} \mathrm{NO}_{8} \mathrm{P}$ & 807.5778 & 1 & $\mathrm{M}+\mathrm{H}$ & \\
\hline Phosphatidylglycerol (31:3) & $\mathrm{C}_{37} \mathrm{H}_{67} \mathrm{O}_{10} \mathrm{P}$ & 702.4471 & 5 & $\mathrm{M}+\mathrm{H}-\mathrm{H} 20$ & \\
\hline
\end{tabular}


Table 2. Cytotoxic activity of crude extract from chloroform extraction (USBA 371 cultured in TSB 3\% $(w / v) \mathrm{NaCl})$ and the isolated compounds against cell lines MCF-7 and $4 \mathrm{~T} 1$.

\begin{tabular}{ccc}
\hline & \multicolumn{2}{c}{ Cytotoxic Activity IC 50 } \\
\hline Strain/Fraction & \multicolumn{2}{c}{ Cellular Line } \\
\hline & MCF-7 & $4 \mathrm{~T} 1$ \\
Strain USBA 371 & $4.5 \pm 1.3 \mu \mathrm{g} / \mathrm{mL}$ & $5.5 \pm 3.44 \mu \mathrm{g} / \mathrm{mL}$ \\
Compound 1 & $87.74 \pm 2.32$ & $57.09 \pm 2.11 \mu \mathrm{M}$ \\
Compound 2 & $890.53 \pm 3.45 \mu \mathrm{M}$ & $875.93 \pm 5.14 \mu \mathrm{M}$ \\
Compound mix 3a and 3b & $16.10 \pm 1.66 \mu \mathrm{g} / \mathrm{mL}$ & $13.41 \pm 1.64 \mu \mathrm{g} / \mathrm{mL}$ \\
\hline
\end{tabular}

Table 3. Cytotoxic activity of compound $\mathbf{1}$ against tumor cell models.

\begin{tabular}{|c|c|c|c|}
\hline \multicolumn{2}{|c|}{ Cell Line } & $\begin{array}{l}\text { Cytotoxic Activity of Fractions } \\
\qquad \mathrm{IC}_{50}(\mu \mathrm{M}) \\
\text { Compound } 1\end{array}$ & $\begin{array}{l}\text { Selectivity Index } \\
\text { (SI) }\end{array}$ \\
\hline \multirow{2}{*}{ Murine Breast Cancer } & $4 \mathrm{~T} 1 \mathrm{H} 17$ * & $40.38 \pm 1.94$ & 7.78 \\
\hline & TSA & $196.66 \pm 4.18$ & 1.59 \\
\hline Murine Melanoma & B16 & $80.87 \pm 3.67$ & 3.88 \\
\hline Murine Colon & MCA 38 & $29.85 \pm 1.55$ & 10.52 \\
\hline \multirow[b]{2}{*}{ Human Uterus Sarcome } & MES-SA/DX5P-Pgp (+) & $225.28 \pm 1.23$ & 1.39 \\
\hline & MES-SA/DX5P-Ppg (-) & $91.32 \pm 5.64$ & 3.44 \\
\hline Lung & $3 \mathrm{LL}$ & $51.71 \pm 0.55$ & 6.07 \\
\hline \multirow{2}{*}{ Myeloid Acute Leukemia } & K562 & ND & ND \\
\hline & U937 & ND & ND \\
\hline Murine Fibroblast & $3 \mathrm{~T} 3$ & $314.30 \pm 3.41$ & ND \\
\hline
\end{tabular}

Selectivity index indicates fractions toxic to tumor model compared to healthy cells $(>1)$ or vice versa $(<1)$. ND: Not detected. * Murine tumor cell line with high ALDH+ expression and high chemotherapy resistance [36].

Taking into consideration the complex dynamics of cancer and tumor models, it is necessary to evaluate the proliferation, metabolism, secretome and antigenicity of the tested cell lines. Here, compound 1 showed high selectivity for cancer cell lines, even against those displaying high drug resistance (Table 3). The highest cytotoxic activity was detected in the $\mathbf{3 a}$ and $\mathbf{3 b} \mathbf{b}$ mix of DKPs (cyclo (L-Phe-L-Pro) and cyclo (L-Ala-L-Pro), but the extracts yielded low quantities and this fraction was not used for further analyses. However, these results support the importance of studying metabolites with antitumoral activity in strain USBA 371. A common characteristic in the compounds here isolated is the presence of proline. It has been shown that DKPs containing proline such as cyclo (L-Pro-L-Tyr), cyclo (D-Pro-L-Phe), cyclo (D-Pro-L-Leu), cyclo (L-Pro-L-Met) and cyclo (L-Pro-D-Tyr) have biological activity against phytopathogenic fungi [37]. Extracts from Pseudomonas aeruginosa PAO1 containing a mix of DKPs cyclo (L-Pro-L-Tyr), cyclo (L-Pro-L-Val) and cyclo (L-Pro-L-Phe) showed activity against HeLa cervical carcinoma and Caco-2 colorectal adenocarcinoma cells $\left(\mathrm{IC}_{50} 0.53\right.$ and $0.66 \mathrm{mg} / \mathrm{mL}$, respectively) [38]. The DKPs cyclo-(L-Val-L-Pro), cyclo-(L-Leu-L-Pro) and cyclo-(L-Phe-L-Pro) isolated from the endophytic strain Streptomyces SUK 25, have antimicrobial activity against methicillin-resistant Staphylococcus aureus and Enterococcus raffinosus, and low toxicity against HepaRG cell line from human hepatoma [23]. DKPs have also been isolated from microorganisms such as Vibrio sp., Haloterrigena hispanica and Bacillus sp. with antifungal and antibacterial activities [19,20,37]. DKPs cyclo (L-Leu-L-Pro) and cyclo (L-Phe-L-Pro) have shown activity against influenza A virus (H3N2) [39]. Iimura et al., (2017) showed that cyclo (L-Ala-L-Pro) inhibits the production of aflatoxines in the fungus Aspergillus flavus [40]. It has been shown that these DKPs play a role in different metabolic activities. In Pseudomonas aeruginosa, Proteus mirabilis and Citrobacter freundii, cyclo (L-Pro-L-Tyr) activates N-acylhomoserine lactones (AHLs) and it is also capable of activating or antagonizing the LuxR-based quorum-sensing systems [41]. 
This is the first report of DKPs isolated from the halophilic genus Labrenzia showing cytotoxic activity against human and murine tumor models. To shed light on the DKPs and secondary metabolite production potential of strain USBA 371, we sequenced and analyzed its genome for metabolic routes that could lead to DKPs and secondary metabolites production.

\subsection{Secondary Metabolite Profiling, Genome Mining and Proteomics}

The draft genome of L. aggregrata USBA 371 is composed of $6,417,675$ bp with a calculated G + C content of $59.14 \%$. It encodes 5916 protein coding genes, of which 4800 have a known function based on sequence similarity. We identified the 16S rRNA gene using the RNAmmer (v1.2) software and confirmed strain USBA 371 classification as L. aggregata with 99\% similarity with the reference strain. The properties and statistics of the genome are summarized in Tables S1 and S2. The distribution of genes into clusters of orthologous groups (COGs) functional categories shows that most of them are involved in amino acid transport and metabolism $(599,10.2 \%)$, transcription $(559,9.5 \%)$ and carbohydrate transport and metabolism (527, 9.0\%) categories (Figure S12). A total of 226 (3.8\%) of the genes are involved in secondary metabolites biosynthesis, transport and catabolism.

The analysis for the presence of secondary metabolite biosynthetic gene clusters (BGCs) of ten strains belonging to four species of Labrenzia (L. aggregata, L. alba, L. marina and L. suaedae), including strain USBA 371, was performed using the IMG/MER platform. Our results reveal predominant clusters of NRPS genes, terpenes, bacteriocins, betalactones, $N$-acetylglutaminylglutamine amide (NAGGN) and type I PKS (Table 4).

In strain USBA 371, seven BGCs detected using antiSMASH [42] correspond to two NRPS, one type-I PKS, one NRPS-t1 PKS, one terpene, one bacteriocin and one betalactone. The bacteriocin, betalactone, terpene and TI PKS BGCs are not closely related to any known gene cluster, suggesting that novel BGC families could be discovered. The NRPS-T1PKS and NRPS show low sequence similarity (4\% and $30 \%$, respectively) to sporolide-nrps-t1pks and Turnerbactin, respectively (Table 5).

The cyclodipeptide synthases (CDPSs) are a family of enzymes that form a peptide bond between the amino acids of two aminoacyl-tRNAs (aa-tRNAs) that are used as substrate for formation of DKPs scaffolds [43]. We used the antiSMASH [42] and PRISM version 4.4 .3 [44] tools for the discovery and classification of BGCs associated to CDPS [45] but failed to detect the presence of any CDPSs. A search of specific conserved domains related with domain/superfamily, functional sites and structural motif annotations for CDPS allowed the detection of 21,162 different domains of which none corresponded to CDPS. This would suggest that DKP production might be through NRPS enzymes, although the NRPSs detected in USBA 371 do not explain the production of DKPs reported in this study.

The hybrid NRP-T1PKS corresponds to a BGC with four adenylation domains specific for the activation of serine, valine, phenylalanine and glycine according to PRISM version 4.4.3 annotation, while antiSMASH predicts the formation of the peptide nrp-valine-tyrosine-glycine. The BGC has thiolation, condensation, epimerization and thioesterase domains (Figure 1).

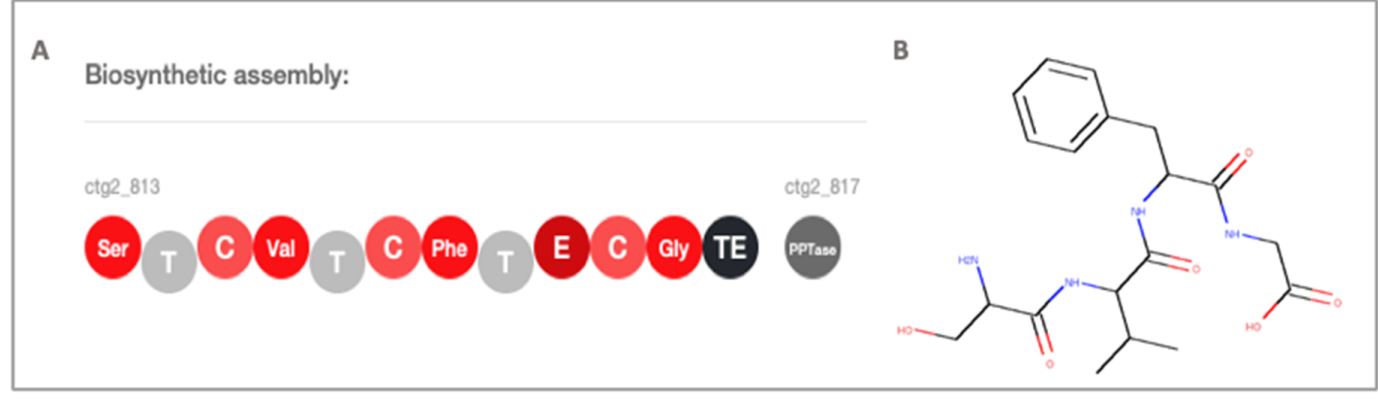

Figure 1. (A) PRISM version 4.4.3 prediction of the NRPS-T1PKS BGC, Ser: Serine adenylation domain, T: thiolation or peptidyl carrier protein, C: condensation, Val: Valine-adenylation domain, Phe: Phenylalanine—adenylation domain, E: epimerization, Gly: Glycine—adenylation domain, TE: thioesterase, PPTase: Phosphopantetheinyltransferase. (B) PRISM version 4.4.3 predicted cluster product. 
Table 4. Number and type of biosynthetic gene cluster groups obtained from 10 strains of Labrenzia genus.

\begin{tabular}{|c|c|c|c|c|c|c|c|c|c|c|}
\hline $\begin{array}{l}\text { Biosynthetic } \\
\text { Gene Cluster } \\
\text { (BGC) Type * }\end{array}$ & $\begin{array}{c}\text { Labrenzia } \\
\text { Aggregata Strain } \\
\text { USBA } 371\end{array}$ & $\begin{array}{l}\text { Labrenzia } \\
\text { Aggregata } \\
\text { CECT } 4801\end{array}$ & $\begin{array}{c}\text { Labrenzia } \\
\text { Aggregata } \\
\text { LZB033 }\end{array}$ & $\begin{array}{l}\text { Labrenzia } \\
\text { Marina } \\
\text { DSM } 17023\end{array}$ & $\begin{array}{l}\text { Labrenzia } \\
\text { Suaedae } \\
\text { DSM } 22153\end{array}$ & $\begin{array}{c}\text { Labrenzia } \\
\text { Alba CECT } \\
5096\end{array}$ & $\begin{array}{c}\text { Labrenzia } \\
\text { Alba CECT } \\
7551\end{array}$ & $\begin{array}{l}\text { Labrenzia } \\
\text { Alba VG12 }\end{array}$ & $\begin{array}{l}\text { Labrenzia } \\
\text { Alba CECT } \\
5095\end{array}$ & $\begin{array}{c}\text { Labrenzia } \\
\text { Alba CECT } \\
\quad 5094\end{array}$ \\
\hline Betalactone & 1 & 1 & 1 & 2 & 2 & 1 & 1 & 1 & 1 & 1 \\
\hline Bacteriocin & 1 & 1 & 1 & 1 & 2 & 1 & 1 & 1 & 1 & 1 \\
\hline $\begin{array}{c}\text { Ectoine, } \\
\text { Hserlactone }\end{array}$ & 0 & 0 & 0 & 0 & 0 & 0 & 0 & 0 & 0 & 0 \\
\hline NAGGN & 1 & 1 & 1 & 1 & 1 & 0 & 0 & 1 & 0 & 0 \\
\hline T1PKS & 1 & 1 & 1 & 1 & 1 & 0 & 1 & 1 & 0 & 0 \\
\hline Terpene & 1 & 1 & 1 & 1 & 1 & 1 & 1 & 1 & 1 & 1 \\
\hline NRPS & 2 & 4 & 6 & 1 & 1 & 0 & 0 & 1 & 0 & 0 \\
\hline $\begin{array}{l}\text { TransAT-PKS, } \\
\text { T3PKS-NRPS }\end{array}$ & 0 & 0 & 0 & 0 & 1 & 1 & 0 & 0 & 1 & 1 \\
\hline Thiopeptide & 0 & 0 & 0 & 0 & 0 & 1 & 0 & 0 & 1 & 1 \\
\hline NRPS-T1PKS & 1 & 0 & 0 & 1 & 0 & 0 & 0 & 0 & 0 & 0 \\
\hline TOTAL BGC & 8 & 9 & 11 & 8 & 8 & 5 & 4 & 6 & 5 & 5 \\
\hline
\end{tabular}

${ }^{*}$ Cluster types according to Integrated Microbial Genomes Atlas of Biosynthetic gene Clusters (IMG-ABC) (https://img.jgi.doe.gov/abc-public). 
Table 5. Biosynthetic gene cluster information. Summary of the antiSMASH biosynthesis cluster prediction in the genome of L. aggregata USBA 371.

\begin{tabular}{cccccc}
\hline $\begin{array}{c}\text { Biosynthetic Gene } \\
\text { Cluster (BGC) Type }\end{array}$ & From & To & $\begin{array}{c}\text { Most Similar Known } \\
\text { Cluster }\end{array}$ & Similarity & $\begin{array}{c}\text { MIBiG } \\
\text { BGC-ID }\end{array}$ \\
\hline NRPS-T1PKS & 872,702 & 926,444 & Sporolide-nrps-t1pks & $4 \%$ & BGC0000150 \\
\hline T1PKS & 963,299 & $1,010,906$ & ND & & \\
\hline Bacteriocin & 125,918 & 136,814 & ND & & \\
\hline Betalactone & 82,927 & 105,536 & ND & & \\
\hline Terpene & 492,697 & 513,548 & ND & & \\
\hline NRPS & 405,475 & 443,932 & Turnerbactin & $30 \%$ & BGC0000451 \\
\hline
\end{tabular}

Although the NRPSpredictor2 in the antiSMASH tool predicts with $100 \%$ certainty that two of the four adenylation domains have specificity for tyr and gly (Stachelhaus code match) amino acids, the substrates for the first two adenylation domains were predicted with a lower certainty $(80 \%)$, suggesting that other amino acids than those predicted could be incorporated. Although the NRPS-T1PKS polypeptide chain cannot be associated with the diversity of DKPs found, it is possible that in case of iterative NRPS, multiple residues of the same amino acids are incorporated iteratively or in non-linear NRPS, which do not follow the domain organization, yielding unexpected products [46].

The second NRPS identified has three condensation domains, two adenylation domains specific for threonine and 2,3-dihydroxybenzoic acid (2,3DHB) activation, one isochorismatase and one thiolation domain (Figure 2). Our proteomic analysis revealed peptides associated to isochorismatase and 2,3-dihydroxybenzoate-AMP ligase (Table S3), suggesting that they could be related to this BGC. We hypothesize that under our experimental conditions, some secondary metabolites may be produced in very low quantities making it difficult to isolate and identify them.

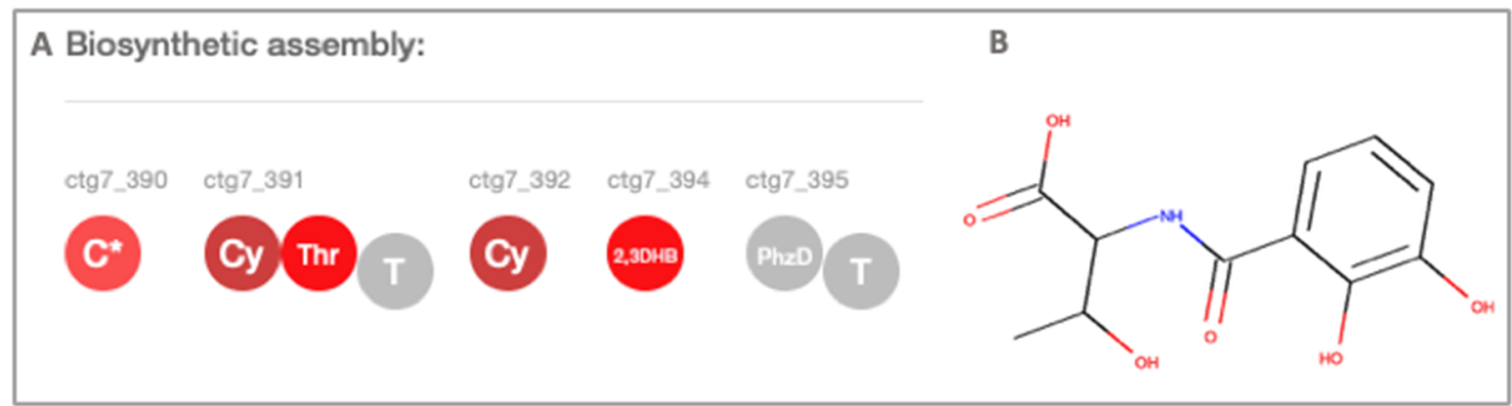

Figure 2. (A) PRISM version 4.4.3 prediction of the NRPS of strain USBA, $C^{*}$ or $C y$ : condensation domain, Thr: Threonine-adenylation domain, T: thiolation or peptidyl carrier protein; 2,3DHB: 2,3-dihydroxybenzoic acid, PhzD: Phenazine biosynthesis isochorismatase. (B) PRISM version 4.4.3 predicted cluster product.

Since we found no evidence for biosynthetic pathways associated with the CDPSs or NRPS, we suggest that they are produced by means of proteolytic enzymes such as dipeptidyl peptidases. They cleave the terminal ends of proteins to generate dipeptides which can then cyclize to form cyclodipeptides (CDPs) [47]. Our analysis identified five genes associated with the production of Xaa-Pro aminopeptidase and one gene associated with the production of Xaa-Pro dipeptidase. Proteomics analysis confirmed the bacterium's production of endopeptidases and exopeptidases with 10 to $153 \mathrm{MS} / \mathrm{MS}$ spectral counts which suggests that they are very abundant in the four biological replicates analyzed (Table S3). 


\section{Materials and Methods}

\subsection{Accession Numbers}

The draft genome of Labrenzia aggregata strain USBA 371 was generated at the DNA Sequencing Core Facility of Los Andes University (GenCore) following standard procedures. The Labrenzia aggregata USBA 371 draft Genome was deposited in the European Nucleotide Archive (ENA) under accession number ERS4291993 and the 16S rRNA gene sequence under accession number MF197928.

\subsection{Culturing Labrenzia aggregata USBA 371 to Obtain Metabolites in Crude Extracts from Chloroform Extraction}

Cultures of strain USBA 371 were grown in TSB (Merck) 3\% (w/v) NaCl in $0.5 \mathrm{~L}$ volumes during $48 \mathrm{~h}$ at $30^{\circ}$ and $160 \mathrm{rpm}$. After cultures reached the stationary phase, they were centrifuged at $9000 \times g$ at $4{ }^{\circ} \mathrm{C}$ for $20 \mathrm{~min}$ to pellet the cells. The cell-free supernatants were extracted three times with chloroform (1:1 ratio) to obtain the chloroform crude extract. The organic phase was collected and evaporated to dryness under reduced pressure using a Buchi Rotavapor R114 (Buchi, Switzerland) and then stored at $-20{ }^{\circ} \mathrm{C}$ in amber glass vials. Uninoculated culture medium was processed in the same way to obtain the medium extract here used as a negative control. Cultures and extractions were performed in three independent replicates.

\subsection{Metabolic Profiling of the Crude Extract from Labrenzia aggregata USBA 371}

Metabolic profiling of the chloroform crude extracts was performed using an HPLC system 1200 series coupled to Q-TOF 6520 (Agilent Technologies, Santa Clara, CA, USA). Chloroform extract of Labrenzia aggregata USBA 371 obtained as described above was used to inject $10 \mu \mathrm{L}$ in a C18 column (Kinetex C18 $150 \mathrm{~mm} \times 2.1 \mathrm{~mm}, 2.6 \mu \mathrm{m}$; Phenomenex) with a guard column (Kinetex C18 $20 \mathrm{~mm} \times 2.1 \mathrm{~mm}, 2.6 \mu \mathrm{m}$; Phenomenex) as stationary phase. Chromatographic analysis was carried out at $40{ }^{\circ} \mathrm{C}$ using a gradient elution consisting of $0.1 \%(v / v)$ formic acid in water (A) and $0.1 \%(v / v)$ formic acid in acetonitrile (B) at a flow rate of $0.3 \mathrm{~mL} / \mathrm{min}$. The eluent gradient started from $25 \% \mathrm{~B}$ to 95\% B in $35 \mathrm{~min}$ and was then kept constant for $10 \mathrm{~min}$. Mass spectrometric detection was performed using electrospray ionization in positive mode in full scan, applying a mass range from 100 to $1200 \mathrm{~m} / \mathrm{z}$. The mass spectrometer source conditions consisted of a capillary voltage of $3500 \mathrm{~V}$ in positive mode, a scan rate of 1.02 scans per second. During all analysis, two reference masses were continuously injected for mass correction: $m / z 121.0509\left(\mathrm{C}_{5} \mathrm{H}_{4} \mathrm{~N}_{4}\right)$ and $m / z 922.0098\left(\mathrm{C}_{18} \mathrm{H}_{18} \mathrm{O}_{6} \mathrm{~N}_{3} \mathrm{P}_{3} \mathrm{~F}_{24}\right)$. Features were putatively identified using the CEU Mass Mediator tool (http://ceumass.eps.uspceu.es/mediator/) [48] by matching the observed accurate mass of each compound with the $m / z$ values available online using the four following databases: METLIN (http://metlin.scripps.edu), KEGG (http://genome.jp/kegg), lipid MAPS (http://lipidMAPS.org), and HMDB (http://hmdb.ca).

\subsection{Isolation of Compounds from Crude Extract of L. aggregata USBA 371}

The crude extract was fractionated by Sephadex LH20 using MeOH as solvent to obtain 8 fractions. Fractions 3 to 5 were pooled and then separated by preparative thin layer chromatography (p-TLC) using $\mathrm{CH}_{2} \mathrm{Cl}_{2}-\mathrm{MeOH}(9: 1)$ to yield compounds $1(15 \mathrm{mg})$ and $2(2 \mathrm{mg})$. Fractions 6 to 8 were also pooled and separated by pTLC using the same discontinuous gradient of $\mathrm{CH}_{2} \mathrm{Cl}_{2}-\mathrm{MeOH}$ to yield the mixture of compounds $\mathbf{3 a}$ and $\mathbf{3 b}(4 \mathrm{mg})$. The identification of compounds $\mathbf{1}, \mathbf{2}, \mathbf{3} \mathbf{a}$ and $\mathbf{3 b}$ was done by NMR using a Bruker Fourier 300MHz. The 1D and 2D NMR data were collected, analyzed and the data were compared with the above-mentioned published in literature.

\subsection{Cytotoxic Activity Assay of Major Compounds Isolated after Chloroform Extraction of Supernatants}

The isolated compounds were resuspended in dimethyl sulfoxide (DMSO) to a final concentration of $25 \mathrm{mg} / \mathrm{mL}$ (stock solution), subsequent dilutions between 250 and $31 \mu \mathrm{g} / \mathrm{mL}$ were used for cytotoxicity assays. The cytotoxic activity was determined by neutral red assay [49], initially against the adherent cell 
lines 4T1 (mouse mammary tumor) and MCF-7 (human mammary adenocarcinoma) followed by H17 y TSA (murine breast cancer), MES SA PGP (+) y MES SA PGP (-) (human uterus sarcome), B16 (murine melanoma), MCA 38 (murine colon), 3 T3 (murine fibroblats) y K562-ATCC, U937 y HL-60/MX2 (myeloid acute leukemia cell line) as described by Díaz-Cárdenas et al., 2017 [15]. When cultures reached a confluence of $80 \%$, cells were passaged and counted in a Neubauer chamber. Cell viability was estimated in triplicate using the trypan blue assay. The percentage of viability was calculated as absorbance of the vehicle/absorbance of the treatment per 100 . Inhibitory concentration $50\left(\mathrm{IC}_{50}\right)$ values were defined as the concentration of the extracts that generated $50 \%$ inhibition of tumor cell growth. $\mathrm{IC}_{50}$ values were calculated with three or four parameter nonlinear regression curves using GraphPad Prism software (GraphPad Software, Inc., San Diego, CA, USA). IC 50 values are presented as the mean \pm standard error of mean (SEM). The selectivity index was calculated using the formula: $\mathrm{IC}_{50}$ Fibroblasts/ $\mathrm{IC}_{50}$ tumor cell. A potential against tumor cell lines was considered when the selectivity was greater than 1 .

The solvent used in the reconstitution of the extract (DMSO) was evaluated as a negative control for each test in the same volume as the extracts. Doxorubicin at a maximum concentration of $5 \mu \mathrm{M}$ was used as a positive control.

\subsection{Proteomic Analysis}

Four independent cultures of strain USBA 371 were grown in TSB 3\% (w/v) $\mathrm{NaCl}$ for $48 \mathrm{~h}$ at $30{ }^{\circ} \mathrm{C}$ and $160 \mathrm{rpm}$ in darkness, and were marked as cultures a, b, c and $\mathrm{d}$. The cultures were centrifuged at $6000 \times \mathrm{g}$ for $30 \mathrm{~min}$ at $4{ }^{\circ} \mathrm{C}$. Then, cells were transferred to $1.5 \mathrm{~mL}$ tubes and resuspended in an equal volume of Laemmli 2X buffer (Tris- $\mathrm{HCl}$ pH $6.865 .8 \mathrm{mM}$, glycerol 26.3\% (v/v), SDS 2.1\% $(v / v)$, bromophenol blue $0.01 \%$ and DTT $50 \mathrm{mM})$. The samples were heated at $99{ }^{\circ} \mathrm{C}$ for $5 \mathrm{~min}$, sonicated for $5 \mathrm{~min}$, and then subjected to bead-beating with a Precellys instrument (Bertin Technology, Montigny-le-Bretonneux, France) at $7800 \mathrm{rpm} 3$ times for $20 \mathrm{~s}$. After a brief centrifugation at $16,000 \times g$ for $1 \mathrm{~min}$, samples were diluted $1 / 2$ in water. Proteins were then subjected to SDS-PAGE migration on a $4-12 \%$ NuPage gradient gel (Invitrogen) with MOPS buffer. After staining with Coomassie BlueSafe stain (Invitrogen), the corresponding polyacrylamide band containing the high molecular weight proteome ( $>200 \mathrm{kDa}$ ) of each sample was sliced, destained, treated with iodoacetamide, and proteolyzed in the presence of detergents to increase peptide recovery with trypsin as previously described [50]. The resulting peptides were resolved on a nanoLC reverse phase column connected to a high-resolution tandem mass spectrometer (Q-exactive HF instrument from Thermo Scientific, MA, USA) operated with a $60 \mathrm{~min}$ gradient in data-dependent acquisition mode. The parameters for MS and MS/MS acquisition were the same as previously described [51]. MS/MS spectra were interpreted against the protein sequence database specific of strain USBA 371 with the MASCOT software (Matrix Science) as described [51]. A list of the identified proteins was established (false discovery rate (FDR) below $1 \%$ as assessed with a decoy search), and their quantities were evaluated based on their spectral counts.

\subsection{Genome Sequencing, Assembly and Annotation}

Labrenzia aggregata USBA 371 was grown on $5 \mathrm{~mL}$ of Marine Medium 2216 (Difco) at $30{ }^{\circ} \mathrm{C}$ for $24 \mathrm{~h}$ and $160 \mathrm{rpm}$. Cells were harvested by centrifugation at $4000 \mathrm{rpm}$ when the mid exponential phase was reached, pelleted and immediately used for DNA extraction. We extracted the genomic DNA using the Wizard ${ }^{\circledR}$ Genomic DNA Purification Kit (Promega) according to the manufacturer's instructions. Illumina 250PE insert standard shotgun library was designed and sequenced using an Illumina HiSeq. Raw reads were analyzed using FastQC (v0.11.2) (http://www.bioinformatics.bbsrc. ac.uk/projects/fastqc/), filtering of data (phred score $<30$, read length $<80 \mathrm{bp}$ and PCR-sequencing adapters) was performed using Trimmomatic (v0.36) [52]. Remaining reads were assembled using SPADES (v3.9) [53]. 
Due to an oversized assembly (10 Mbp against 6.5 Mbp of the reference L. aggregata genome, accesion number NZ_CP019630.1), filtered reads were processed and re-assembled after running a Blastn against nt database. Genes were identified using the U.S. Department of Energy (DOE) Joint Genome Institute (JGI) (DOE-JGI) genome annotation pipeline [54], and functional annotation was performed within the Integrated Microbial Genomes (IMG) platform [54] and RASTtk [55] protocol. The USBA 371 annotated Genome was uploaded to the GOLD database under the Integrated Microbial Genomes (IMG) ID accession number 2827789216. The assembled genome was processed for secondary metabolites detection using web tool antiSMASH (v2.0) [42] (http://antismash.secondarymetabolites.org/), and PRISM version 4.4.3 [44]. A search of specific conserved domains related with domain/superfamily, functional sites and structural motif annotations for CDPs and NRPs in JGI-annotated genome was performed through rpsBlastn against the conserved domain database (CDD) (https://www.ncbi.nlm.nih.gov/cdd/). Output matches were processed through rpsbproc utility using an E-value of 0.01 and a concise level of redundancy of domain hit.

The exploration of microbial secondary metabolism in Labrenzia spp., were done using the Integrated Microbial Genomes Atlas of Biosynthetic gene Clusters (IMG-ABC) (https://img.jgi.doe.gov/ abc-public), a publicly available database of predicted biosynthetic gene clusters [56].

\section{Conclusion and Perspectives}

We show that USBA 371 extracts contain bioactive metabolites and DKPs with cytotoxic activity against human and murine tumor models. This study paves the way for evaluating the pharmacological properties and therapeutic potential of metabolites identified in USBA 371. Since levels of biological activity of crude extracts are higher than those of the compounds that were isolated, it remains to be determined whether the use of complex mixtures of bacterial extracts that present biological activities with high therapeutic potential is feasible. If it is, it would open an interesting path in the search for active molecular complexes beyond isolated compounds which could become an innovative vision in the search for antitumor drugs.

In addition, the introduction of the Labrenzia genus to bioprospecting is likely to lead to the identification of other secondary metabolites, especially considering that information from the BGCs that we have identified has opened a new line of research that is likely lead to the discovery of new metabolites.

Supplementary Materials: The Supplementary Materials are available online at http://www.mdpi.com/1420-3049/ 25/11/2546/s1, Figure S1: 1H-NMR for compound 1 ( $\left.\mathrm{CDCl}_{3}, 300 \mathrm{MHz}\right)$, Figure S2: ${ }^{13} \mathrm{C}-\mathrm{NMR}$ for compound 1 $\left(\mathrm{CDCl}_{3}, 75 \mathrm{MHz}\right)$, Figure S3: HSQC spectrum for compound $\mathbf{1}\left(\mathrm{CDCl}_{3}, 300 \mathrm{MHz}\right)$, Figure S4: COSY H-H spectrum for compound $1\left(\mathrm{CDCl}_{3}, 300 \mathrm{MHz}\right)$, Figure S5: HMBC spectrum for compound $1\left(\mathrm{CDCl}_{3}, 300 \mathrm{MHz}\right)$, Figure S6: ${ }^{1} \mathrm{H}-\mathrm{NMR}$ for compound $2\left(\mathrm{CDCl}_{3}, 300 \mathrm{MHz}\right)$, Figure S7: ${ }^{13} \mathrm{C}-\mathrm{NMR}$ for compound $2\left(\mathrm{CDCl}_{3}, 75 \mathrm{MHz}\right)$, Figure S8: ${ }^{1} \mathrm{H}-\mathrm{NMR}$ for the mixture of compounds $\mathbf{3 a}$ and $\mathbf{3 b}\left(\mathrm{CDCl}_{3}, 300 \mathrm{MHz}\right)$, Figure S9: ${ }^{13} \mathrm{C}-\mathrm{NMR}$ for the mixture of compounds $3 \mathbf{a}$ and $\mathbf{3 b}\left(\mathrm{CDCl}_{3}, 75 \mathrm{MHz}\right)$, Figure S10: The cytotoxic activity of the crude extract, compounds 1 and $\mathbf{2}$, and the mix of compounds $\mathbf{3 a}$ and $\mathbf{3 b}$ assessed against cell lines 4T1 (A) and MCF-7 (B), Figure S11: The cytotoxic activity of compound 1 against (A) Murine melanoma cell line B16; (B) murine colon cell line MCA 38; (C) Human uterus sarcoma cell line; (D) Lung cancer cell line 3LL; (E) Murine fibroblast cell line 3T3; (F) Myeloid acute leukemia cell line K562; (G) Myeloid acute leukemia cell line U937, Figure S12: Gene categories associated with general COG functional categories in Labrenzia aggregata strain USBA 371, Table S1: Quast statistics for assembly, Table S2: Genome statistics of Labrenzia aggregata USBA371, Table S3: List of proteins detected in Labrenzia aggregata USBA 371 using proteomic analysis.

Author Contributions: C.D.-C., S.R., S.F., and S.B. conceived and designed the study. C.D.-C. and L.Y.R. performed the experiments. M.P.C. performed the lipid profiling by LC-MS. F.A.R. analyzed the data of chemical profiles of metabolites. J.I.D. analyzed the genomic data. J.A. analyzed the data of proteomics profiles. C.D.-C. and S.B. wrote the paper. S.R., S.F., J.A. and F.A.R. critically reviewed and edited the manuscript. All authors have read and agreed to the published version of the manuscript.

Funding: This research was funded by the Ministry of Sciences (Formerly Instituto Colombiano para el Desarrollo de la Ciencia y la Tecnología (Grand Colciencias-Contract RC 0016-2013), Pontificia Universidad Javeriana and Universidad de los Andes. It was done under MAVDT contract No. 0104. 
Acknowledgments: We thank the DNA Sequencing Core Facility of Los Andes University (GenCore) which performed the Illumina or ION Genestudio S5 sequencing and library construction. The sequencing Core facility is part of the Vice-presidency of Research of Los Andes University.

Conflicts of Interest: The authors declare no conflict of interest.

\section{References}

1. Sinha, S.; Nge, C.E.; Leong, C.Y.; Ng, V.; Crasta, S.; Alfatah, M.; Goh, F.; Low, K.N.; Zhang, H.; Arumugam, P.; et al. Genomics-driven discovery of a biosynthetic gene cluster required for the synthesis of BII-Rafflesfungin from the fungus Phoma sp. F3723. BMC Genom. 2019, 20, 374. [CrossRef] [PubMed]

2. Quadri, I.; Hassani, I.I.; L’Haridon, S.; Chalopin, M.; Hacène, H.; Jebbar, M. Characterization and antimicrobial potential of extremely halophilic archaea isolated from hypersaline environments of the Algerian Sahara. Microbiol. Res. 2016, 186, 119-131. [CrossRef] [PubMed]

3. Chen, L.; Wang, G.; Bu, T.; Zhang, Y.; Wang, Y.; Liu, M.; Lin, X. Phylogenetic analysis and screening of antimicrobial and cytotoxic activities of moderately halophilic bacteria isolated from the Weihai Solar Saltern (China). World J. Microbiol. Biotechnol. 2010, 26, 879-888. [CrossRef]

4. Chen, L.; Wang, X.-N.; Fu, C.-M.; Wang, G.-Y. Phylogenetic Analysis and Screening of Antimicrobial and Antiproliferative Activities of Culturable Bacteria Associated with the Ascidian Styela clava from the Yellow Sea, China. BioMed Res. Int. 2019, 2019, 1-14. [CrossRef]

5. Mazguene, S.; Rossi, M.; Gogliettino, M.; Palmieri, G.; Cocca, E.; Mirino, S.; Imadalou-Idres, N.; Benallaoua, S. Isolation and characterization from solar salterns of North Algeria of a haloarchaeon producing a new halocin. Extremophiles 2018, 22, 259-270. [CrossRef]

6. Tang, X.-X.; Liu, S.-Z.; Yan, X.; Tang, B.-W.; Fang, M.-J.; Wang, X.-M.; Wu, Z.; Qiu, Y.-K. Two New Cytotoxic Compounds from a Deep-Sea Penicillum citreonigrum XT20-134. Mar. Drugs 2019, 17, 509. [CrossRef]

7. Karthikeyan, P.; Bhat, S.G.; Chandrasekaran, M. Halocin SH10 production by an extreme haloarchaeon Natrinema sp. BTSH10 isolated from salt pans of South India. Saudi J. Biol. Sci. 2013, 20, 205-212. [CrossRef]

8. Camacho, M.; Redondo-Gómez, S.; Rodrìguez-Llorente, I.; Rohde, M.; Spröer, C.; Schumann, P.; Klenk, H.P.; del Carmen Montero-Calasanz, M. Labrenzia salina sp. Nov., isolated from the rhizosphere of the halophyte Arthrocnemum macrostachyum. Int. J. Syst. Evol. Microbiol. 2016, 66, 5173-5180. [CrossRef]

9. Rodrigues, G.N.; Lago-Lestón, A.; Costa, R.; Keller-Costa, T. Draft genome sequence of Labrenzia sp. strain EL143, a coral-associated alphaproteobacterium with versatile symbiotic living capability and strong halogen degradation potential. Genome Announc. 2018, 6, 1-2. [CrossRef]

10. Biebl, H.; Pukall, R.; Lünsdorf, H.; Schulz, S.; Allgaier, M.; Tindall, B.J.; Wagner-Döbler, I. Description of Labrenzia alexandrii gen. nov., sp. nov., a novel alphaproteobacterium containing bacteriochlorophyll a, and a proposal reclassification of Stappia aggregata as Labrenzia aggregata comb. nov., and of Stappia alba as Labrenzia alba comb. nov. Int. J. Syst. Evol. Microbiol. 2007, 57, 1095-1107. [CrossRef]

11. Kačar, D.; Schleissner, C.; Cañedo, L.M.; Rodríguez, P.; de la Calle, F.; Galán, B.; García, J.L. Genome of Labrenzia sp. PHM005 Reveals a Complete and Active Trans-AT PKS Gene Cluster for the Biosynthesis of Labrenzin. Front. Microbiol. 2019, 10, 2561. [CrossRef] [PubMed]

12. Schleissner, C.; Cañedo, L.M.; Rodríguez, P.; Crespo, C.; Zúñiga, P.; Peñalver, A.; De La Calle, F.; Cuevas, C. Bacterial Production of a Pederin Analogue by a Free-Living Marine Alphaproteobacterium. J. Nat. Prod. 2017, 80, 2170-2173. [CrossRef] [PubMed]

13. Raj Sharma, A.; Zhou, T.; Harunari, E.; Oku, N.; Trianto, A.; Igarashi, Y. Labrenzbactin from a coral-associated bacterium Labrenzia sp. J. Antibiot. (Tokyo) 2019, 72, 634-639. [CrossRef] [PubMed]

14. Moghaddam, J.A.; Dávila-Céspedes, A.; Kehraus, S.; Crüsemann, M.; Köse, M.; Müller, C.E.; König, G.M. Cyclopropane-containing fatty acids from the marine bacterium Labrenzia sp. 011 with antimicrobial and GPR84 activity. Mar. Drugs 2018, 16, 369. [CrossRef]

15. Díaz-Cárdenas, C.; Cantillo, A.; Rojas, L.Y.; Sandoval, T.; Fiorentino, S.; Robles, J.; Ramos, F.A.; Zambrano, M.M.; Baena, S. Microbial diversity of saline environments: Searching for cytotoxic activities. $A M B$ Express 2017, 7, 223. [CrossRef]

16. Borthwick, A.D.; Da Costa, N.C. 2,5-diketopiperazines in food and beverages: Taste and bioactivity. Crit. Rev. Food Sci. Nutr. 2017, 57, 718-742. [CrossRef] 
17. Lautru, S.; Gondry, M.; Genet, R.; Pernodet, J.L. The albonoursin gene cluster of S. noursei: Biosynthesis of diketopiperazine metabolites independent of nonribosomal peptide synthetases. Chem. Biol. 2002, 9, 1355-1364. [CrossRef]

18. Yao, T.; Liu, J.; Liu, Z.; Li, T.; Li, H.; Che, Q.; Zhu, T.; Li, D.; Gu, Q.; Li, W. Genome mining of cyclodipeptide synthases unravels unusual tRNA-dependent diketopiperazine-terpene biosynthetic machinery. Nat. Commun. 2018, 9, 4091. [CrossRef]

19. Tommonaro, G.; Abbamondi, G.R.; Iodice, C.; Tait, K.; De Rosa, S. Diketopiperazines Produced by the Halophilic Archaeon, Haloterrigena hispanica, Activate AHL Bioreporters. Microb. Ecol. 2012, 63, 490-495. [CrossRef]

20. Nishanth Kumar, S.; Mohandas, C.; Siji, J.V.; Rajasekharan, K.N.; Nambisan, B. Identification of antimicrobial compound, diketopiperazines, from a Bacillus sp. $\mathrm{N}$ strain associated with a rhabditid entomopathogenic nematode against major plant pathogenic fungi. J. Appl. Microbiol. 2012, 113, 914-924. [CrossRef]

21. Fdhila, F.; Vázquez, V.; Sánchez, J.L.; Riguera, R. dd-diketopiperazines: Antibiotics active against Vibrio anguillarum isolated from marine bacteria associated with cultures of Pecten maximus. J. Nat. Prod. 2003, 66, 1299-1301. [CrossRef] [PubMed]

22. Kang, H.; Ku, S.K.; Choi, H.; Bae, J.S. Three diketopiperazines from marine-derived bacteria inhibit LPS-induced endothelial inflammatory responses. Bioorganic Med. Chem. Lett. 2016, 26, 1873-1876. [CrossRef] [PubMed]

23. Alshaibani, M.M.; Zin, N.; Jalil, J.; Sidik, N.M.; Ahmad, S.J.; Kamal, N.; Edrada-Ebel, R. Isolation, Purification, and Characterization of Five Active Diketopiperazine Derivatives from Endophytic Streptomyces SUK 25 with Antimicrobial and Cytotoxic Activities. J. Microbiol. Biotechnol. 2017, 27, 1249-1256. [CrossRef] [PubMed]

24. van der Merwe, E.; Huang, D.; Peterson, D.; Kilian, G.; Milne, P.J.; Van de Venter, M.; Frost, C. The synthesis and anticancer activity of selected diketopiperazines. Peptides 2008, 29, 1305-1311. [CrossRef]

25. Gomes, N.G.M.; Pereira, R.B.; Andrade, P.B.; Valentão, P. Double the chemistry, double the fun: Structural diversity and biological activity of marine-derived diketopiperazine dimers. Mar. Drugs 2019, 17, 551. [CrossRef]

26. Martins, M.B.; Carvalho, I. Diketopiperazines: Biological activity and synthesis. Tetrahedron 2007, 63, 9923-9932. [CrossRef]

27. Yonezawa, K.; Yamada, K.; Kouno, I. New Diketopiperazine Derivatives Isolated from Sea Urchin-Derived Bacillus sp. Chem. Pharm. Bull. 2011, 59, 106-108. [CrossRef]

28. Stierle, A.C.; Cardellina, J.H.; Strobel, G.A. Maculosin, a host-specific phytotoxin for spotted knapweed from Alternaria alternata. Proc. Natl. Acad. Sci. USA 1988, 85, 8008-8011. [CrossRef]

29. Azab, A.; Nassar, A.; Azab, A.N. Anti-inflammatory activity of natural products. Molecules 2016, $21,1321$. [CrossRef]

30. Deharo, E.; Ginsburg, H. Analysis of additivity and synergism in the anti-plasmodial effect of purified compounds from plant extracts. Malar. J. 2011, 10, S5. [CrossRef]

31. Prieto, K.; Cao, Y.; Mohamed, E.; Trillo-Tinoco, J.; Sierra, R.A.; Urueña, C.; Sandoval, T.A.; Fiorentino, S.; Rodriguez, P.C.; Barreto, A. Polyphenol-rich extract induces apoptosis with immunogenic markers in melanoma cells through the ER stress-associated kinase PERK. Cell Death Discov. 2019, 5, 1-15. [CrossRef] [PubMed]

32. Sandoval, T.A.; Urueña, C.P.; Llano, M.; Gómez-Cadena, A.; Hernández, J.F.; Sequeda, L.G.; Loaiza, A.E.; Barreto, A.; Li, S.; Fiorentino, S. Standardized Extract from Caesalpinia spinosa is Cytotoxic over Cancer Stem Cells and Enhance Anticancer Activity of Doxorubicin. Am. J. Chin. Med. 2016, 44, 1693-1717. [CrossRef] [PubMed]

33. Adams, L.S.; Seeram, N.P.; Hardy, M.L.; Carpenter, C.; Heber, D. Analysis of the interactions of botanical extract combinations against the viability of prostate cancer cell lines. Evid.-Based Complement. Altern. Med. 2006, 3, 117-124. [CrossRef] [PubMed]

34. Lin, Y.J.; Liang, W.M.; Chen, C.J.; Tsang, H.; Chiou, J.S.; Liu, X.; Cheng, C.F.; Lin, T.H.; Liao, C.C.; Huang, S.M.; et al. Network analysis and mechanisms of action of Chinese herb-related natural compounds in lung cancer cells. Phytomedicine 2019, 58, 152893. [CrossRef] [PubMed]

35. Yuan, H.; Ma, Q.; Cui, H.; Liu, G.; Zhao, X.; Li, W.; Piao, G. How can synergism of traditional medicines benefit from network pharmacology? Molecules 2017, 22, 1135. [CrossRef] 
36. Lasso, P.; Llano Murcia, M.; Sandoval, T.A.; Urueña, C.; Barreto, A.; Fiorentino, S. Breast Tumor Cells Highly Resistant to Drugs Are Controlled Only by the Immune Response Induced in an Immunocompetent Mouse Model. Integr. Cancer Ther. 2019, 18, 1-16. [CrossRef]

37. Nishanth Kumar, S.; Mohandas, C.; Nambisan, B.; Kumar, D.R.S.; Lankalapalli, R.S. Isolation of proline-based cyclic dipeptides from Bacillus sp. N strain associated with rhabitid entomopathogenic nematode and its antimicrobial properties. World J. Microbiol. Biotechnol. 2013, 29, 355-364. [CrossRef]

38. Vázquez-Rivera, D.; González, O.; Guzmán-Rodríguez, J.; Díaz-Pérez, A.L.; Ochoa-Zarzosa, A.; López-Bucio, J.; Meza-Carmen, V.; Campos-García, J. Cytotoxicity of cyclodipeptides from pseudomonas aeruginosa PAO1 leads to apoptosis in human cancer cell lines. BioMed Res. Int. 2015, 2015, 9. [CrossRef]

39. Kwak, M.-K.; Liu, R.; Kwon, J.-O.; Kim, M.-K.; Kim, A.H.; Kang, S.-O. Cyclic dipeptides from lactic acid bacteria inhibit proliferation of the influenza A virus. J. Microbiol. 2013, 51, 836-843. [CrossRef]

40. Iimura, K.; Furukawa, T.; Yamamoto, T.; Negishi, L.; Suzuki, M.; Sakuda, S. The Mode of Action of Cyclo(L-Ala-L-Pro) in Inhibiting Aflatoxin Production of Aspergillus flavus. Toxins 2017, 9, 219. [CrossRef]

41. Holden, M.T.G.; Chhabra, S.R.; De Nys, R.; Stead, P.; Bainton, N.J.; Hill, P.J.; Manefield, M.; Kumar, N.; Labatte, M.; England, D.; et al. Quorum-sensing cross talk: Isolation and chemical characterization of cyclic dipeptides from Pseudomonas aeruginosa and other Gram-negative bacteria. Mol. Microbiol. 1999, 33, 1254-1266. [CrossRef] [PubMed]

42. Weber, T.; Blin, K.; Duddela, S.; Krug, D.; Kim, H.U.; Bruccoleri, R.; Lee, S.Y.; Fischbach, M.A.; Müller, R.; Wohlleben, W.; et al. antiSMASH 3.0-a comprehensive resource for the genome mining of biosynthetic gene clusters. Nucleic Acids Res. 2015, 43, 1-7. [CrossRef] [PubMed]

43. Gondry, M.; Sauguet, L.; Belin, P.; Thai, R.; Amouroux, R.; Tellier, C.; Tuphile, K.; Jacquet, M.; Braud, S.; Courçon, M.; et al. Cyclodipeptide synthases are a family of tRNA-dependent peptide bond-forming enzymes. Nat. Chem. Biol. 2009, 5, 414-420. [CrossRef] [PubMed]

44. Skinnider, M.A.; Merwin, N.J.; Johnston, C.W.; Magarvey, N.A. PRISM 3: Expanded prediction of natural product chemical structures from microbial genomes. Nucleic Acids Res. 2017, 45, W49-W54. [CrossRef] [PubMed]

45. Skinnider, M.A.; Johnston, C.W.; Merwin, N.J.; Dejong, C.A.; Magarvey, N.A. Global analysis of prokaryotic tRNA-derived cyclodipeptide biosynthesis. BMC Genom. 2018, 19, 45. [CrossRef] [PubMed]

46. Shaw-Reid, C.A.; Kelleher, N.L.; Losey, H.C.; Gehring, A.M.; Berg, C.; Walsh, C.T. Assembly line enzymology by multimodular nonribosomal peptide synthetases: The thioesterase domain of E. coil EntF catalyzes both elongation and cyclolactonization. Chem. Biol. 1999, 6, 385-400. [CrossRef]

47. Mishra, A.K.; Choi, J.; Choi, S.J.; Baek, K.H. Cyclodipeptides: An overview of their biosynthesis and biological activity. Molecules 2017, 22, 1796. [CrossRef]

48. Gil de la Fuente, A.; Godzien, J.; Fernández López, M.; Rupérez, F.J.; Barbas, C.; Otero, A. Knowledge-based metabolite annotation tool: CEU Mass Mediator. J. Pharm. Biomed. Anal. 2018, 154, 138-149. [CrossRef]

49. Repetto, G.; del Peso, A.; Zurita, J.L. Neutral red uptake assay for the estimation of cell viability/cytotoxicity. Nat. Protoc. 2008, 3, 1125-1131. [CrossRef]

50. Hartmann, E.M.; Allain, F.; Gaillard, J.C.; Pible, O.; Armengaud, J. Taking the shortcut for high-throughput shotgun proteomic analysis of bacteria. Methods Mol. Biol. 2014, 1197, 275-285.

51. Klein, G.; Mathé, C.; Biola-Clier, M.; Devineau, S.; Drouineau, E.; Hatem, E.; Marichal, L.; Alonso, B.; Gaillard, J.C.; Lagniel, G.; et al. RNA-binding proteins are a major target of silica nanoparticles in cell extracts. Nanotoxicology 2016, 10, 1555-1564. [CrossRef] [PubMed]

52. Bolger, A.M.; Lohse, M.; Usadel, B. Trimmomatic: A flexible trimmer for Illumina sequence data. Bioinformatics 2014, 30, 2114-2120. [CrossRef] [PubMed]

53. Bankevich, A.; Nurk, S.; Antipov, D.; Gurevich, A.A.; Dvorkin, M.; Kulikov, A.S.; Lesin, V.M.; Nikolenko, S.I.; Pham, S.; Prjibelski, A.D.; et al. SPAdes: A New Genome Assembly Algorithm and Its Applications to Single-Cell Sequencing. J. Comput. Biol. 2012, 19, 455-477. [CrossRef] [PubMed]

54. Huntemann, M.; Ivanova, N.N.; Mavromatis, K.; Tripp, H.J.; Paez-Espino, D.; Palaniappan, K.; Szeto, E.; Pillay, M.; Chen, I.-M.A.; Pati, A.; et al. The standard operating procedure of the DOE-JGI Microbial Genome Annotation Pipeline (MGAP v.4). Stand. Genom. Sci. 2015, 10, 86. [CrossRef] [PubMed] 
55. Brettin, T.; Davis, J.J.; Disz, T.; Edwards, R.A.; Gerdes, S.; Olsen, G.J.; Olson, R.; Overbeek, R.; Parrello, B.; Pusch, G.D.; et al. RASTtk: A modular and extensible implementation of the RAST algorithm for building custom annotation pipelines and annotating batches of genomes. Sci. Rep. 2015, 5, 8365. [CrossRef] [PubMed]

56. Palaniappan, K.; Chen, I.M.A.; Chu, K.; Ratner, A.; Seshadri, R.; Kyrpides, N.C.; Ivanova, N.N.; Mouncey, N.J. IMG-ABC v.5.0: An update to the IMG/Atlas of Biosynthetic Gene Clusters Knowledgebase. Nucleic Acids Res. 2020, 48, D422-D430. [CrossRef]

Sample Availability: Samples of the compounds 1, 2 and mix $\mathbf{3 a}$ and $\mathbf{3 b}$ are available from the authors.

(C) 2020 by the authors. Licensee MDPI, Basel, Switzerland. This article is an open access article distributed under the terms and conditions of the Creative Commons Attribution (CC BY) license (http://creativecommons.org/licenses/by/4.0/). 